\title{
Using of CAD/CAE systems in designing of head for thread drilling on multirate stamp press
}

\author{
Wykorzystanie systemów CAD/CAE w projektowaniu głowicy \\ do gwintowania na prasie wielotaktowej
}

\section{ANDRZEJ PIOTROWSKI *}

The using of CAD/CAE systems in design of head for thread drilling and reaming on multirate stamp press was described. It was presented model of device for thread drilling with the basics calculation. Furthermore, design of special tool for rearming and cutting in one step was described.

KEYWORDS: thread drilling, multirate press, CAD/CAE systems.

The screw connection belongs to the most durable and the most frequently used connections in the world. They can be found practically everywhere: in building constructions of buildings, passenger cars, subassemblies of personal computers, and even in ordinary long writings [2, 3, 23].

The process of creating threads is a popular operation performed in production plants. There are several methods for forming threads. Technological processes together with the tools used in them can be divided into two types - external and internal threading.

As a rule, the threading process is a separate operation and is carried out on lathes and milling machines [1, 8, 15, 24, 25].

The problem presented in the article resulted directly from the needs of the Polish mechanical industry. The company dealing in the production of punching tools on a multi-stroke press requested the development of a threading process in flanges and in thick sheets directly on the press, without the need for additional operations on other types of machines. The result of the cooperation was the development of a process and a universal head enabling threading in a single bar clock, as well as a special tool for punching the hole and reaming with the use of a developed head that converts the sliding movement of the press into a rotational movement of the tool.

\section{Project assumptions}

The tapping heads on the press in the blaster elements are characterized by the possibility of processing the linear movement of the press into the working movement of the tap, in other words - conversion of reciprocating motion into rotary motion [10]. The return of the reciprocating motion changes systematically, while the direction is unchanged and is usually perpendicular to the workpiece. Depending on the design of the threading units, the changes in the return of the rectilinear motion can occur in a harmonic or intermittent way. Rotation is a movement in which all points placed on a given object move in circles whose center is the same and is called the axis of rotation of an object.

Fig. 1 shows the threading unit with the distinction of the reciprocation of the reciprocating movement of the press into the rotary motion of the tap [16]. The head consists of a screw of a ball-and-socket mechanism converting the feed motion into a rotary motion, a gearing that allows adjusting the number of rotations, compression springs and housing.

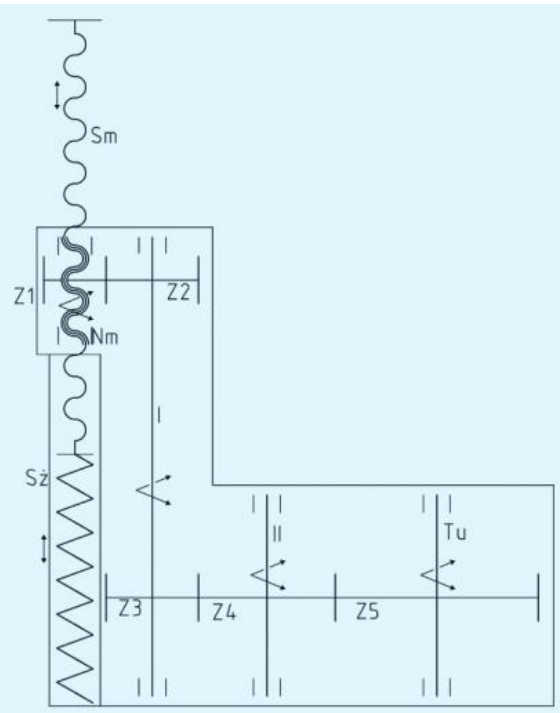

Fig. 1. Kinematic diagram of the threading head on the press: Sm screw of the ball-screw mechanism, Nm - nut, Sż - spring, I - first shaft, II - second shaft, Tu - a special sleeve enabling the holder to be mounted on taps, Z1- Z5 gear transmission consisting of five gears [12]

The decisive factor for the device's parameters was the EUROMET PH40T press owned by the cooperating company, therefore calculations enabling proper design of the tapping head $[4,7,13,14,16]$ were made based on its parameters and the type of pressed sheets. The press has only the working speed of the slider and the speed of the return movement, and there is no additional sliding speed of the slider (which other hydraulic presses are equipped with) [5]. 
Since, in principle, the head was to be universal, with the option of retooling (replacing the screw of the ball-and-socket mechanism and changing the gear ratios of the tooth gear), the CAD/CAE Auto-Desk Inventor 2015 software was used [6]. It allows creating a 3D head mode and modifying the structure by exchanging individual elements (assemblies) of the mechanism. In addition, it has a built-in CAE module that allows you to model the loads of the developed structure. The software also enables automation of the creation of assembly and construction drawings of individual parts of the head [6].

The most important element of the threading head is the ball screw mechanism that converts the reciprocating motion into a rotary motion.

The screw is made of C45 steel with medium hardness [16]. In the case under consideration, the bolt is loaded with axial force from the pressure of the hydraulic press. The axial force induces compressive stresses, while the torque moment causes torsional stress. In addition, bolt strength will be determined by buckling strength.

On both sides, the screw is not fixed in any way (fig. 2 and fig. 3), only on both ends of the bolt are mounted discs increasing the surface, on which on one side will operate the pressure force of the press, and on the other - force pressure of the spring [9, 12]. Therefore, it was assumed that the slenderness of the bolt would have a higher value than the borderline curvature, and the Euler's formula was used.

On this basis, the internal diameter was calculated and the ball screw mechanism with the left-turn screw and the ball thread (table) was adopted. The selected screw with the nut has a fixed pitch, enabling threading with the use of traditional cutting and crimping dies. In the developed tool (fig. 4), the screw has a variable pitch to cut and bore the hole.

TABLE. Parameters of the HIWIN ball screw $[21,22]$

\begin{tabular}{|l|l|}
\hline Inner diameter of the bolt & $d_{\mathrm{w}}=27,8 \mathrm{~mm}$ \\
\hline Outer diameter of the bolt & $d_{z}=32 \mathrm{~mm}$ \\
\hline Thread pitch & $P=10 \mathrm{~mm}$ \\
\hline Diameter of the ball & $d_{\mathrm{k}}=6,35 \mathrm{~mm}$ \\
\hline Maximum axial clearance & $B=0,02 \mathrm{~mm}$ \\
\hline
\end{tabular}

The speed of the nut depends on the speed of the slider stroke and on the thread pitch of the ball screw. For the feed speed of the slider equal to $94 \mathrm{~mm} / \mathrm{s}$ and assuming $95 \%$ efficiency, the rotational speed of the machine nut is 188.4 rpm.

The obtained rotational speed of the nut is transferred to the tap through a toothed gear. The kinematic ratio between successive gears is always equal to $1: 1.5$, which means that the final speed of the tool is $55.8 \mathrm{rpm}$.

The gearing consists of five gears $(Z 1-Z 5)$ with straight teeth and number of teeth: $Z 1=29$ teeth, $Z 2=44$ teeth, $Z 3=$ 44 teeth, $Z 4=66$ teeth, $Z 5=99$ teeth. All calculations were made with the assumption of annual durability $\mathrm{Lh}=6000 \mathrm{~h}$ (ISO 281: 2007) [11, 17-20, 23, 25].

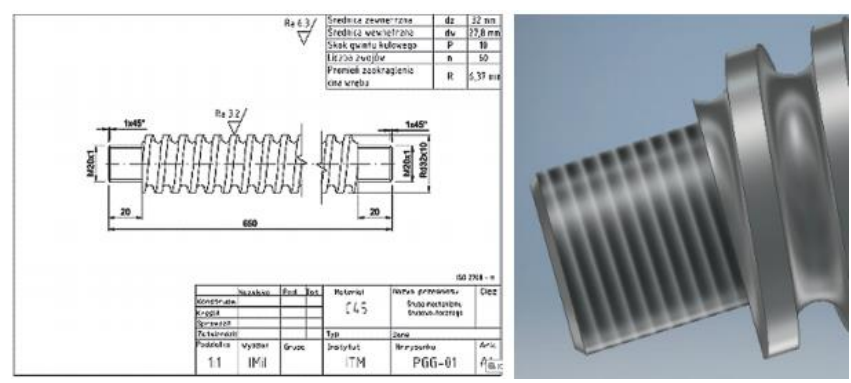

Fig. 2. 3D model of the design and screw mechanism of screw-rolling performed in the Inventor 2015 [6]

In order to compensate for the differences between the feed and the stroke of the thread being machined, a mechanical holder with axial compensation was selected that allows the tap to move axially. In addition, a special driver was used to prevent the tap from being destroyed in the event of a sudden increase in resistance during internal threading or collision during operation.

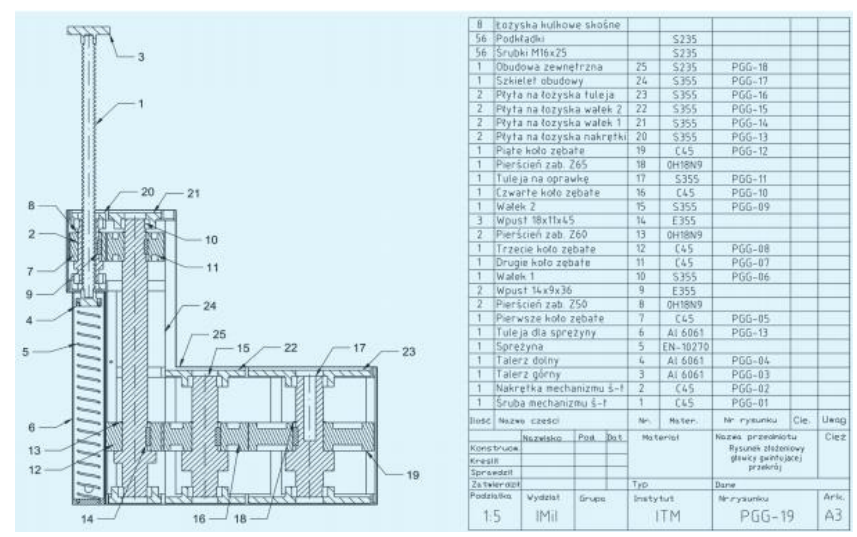

Fig. 3. Assembly drawing of the universal threading head on the press [12] (AutoDesk Inventor 2015 program)

\section{Tool for making and reaming holes}

Developed head is a universal device and can also be used for reaming holes with the use of classic reamers and a special tool that cuts a hole in a single bar of the press and then performs reaming. The only modification is to change the shape of the propeller screw. In the initial part the tooth line must be straight (no rotation) - for punching, and then has a screw shape (turning the tool) - for reaming.

The known technology of making shaped elements, in particular with openings, from various types of sheets in the punching process in a single work cycle on the press consists in using a punch of a shape (in a perpendicular cross-section) consistent with the shape of the hole being punched out. The severed part of the material becomes a waste. During punching - the same as in the case of threading - the punch moves on rectilinear presses in an axis perpendicular to the die surface.

The classic punch design takes into account zero angle of attack, i.e. the lateral surface of the punch is straight-fell to the surface of the die being cut. There are also constructions with a small $\left(2 \div 5^{\circ}\right)$ angle of attack. The pressure force is directed axially, that is, perpendicular to the surface of the matrix.

A side effect of the classical punching process is the small dimensional accuracy of the hole made, falling within the accuracy class IT9 $\div$ IT11. In addition, as a result of the flow, the surface of the hole is frayed at the edges of the punching, and underneath there is a characteristic, small flash.

In the case of high requirements for openings, e.g. fitting $\mathrm{H}$ and accuracy class IT5 $\div \mathrm{IT} 7$, they must be additionally processed in subsequent technological operations on other machine tools, which increases the costs of processing and extends its time. This is particularly important in the case of round holes, made in chimneys formed in several bars of the press, with a height $\mathrm{h} \geq 2.5 \mathrm{~g}$ (where: $h$ - chimney height, $g$ thickness of pressed material). Very often they play the role of base holes and must be performed in high accuracy classes.

The constructed tool (fig. 4) performs two movements during a single bar cycle. The first is the rectilinear axial movement during roughing.

The roughing part (B), with a length of approx. $20 \div 25 \%$ of the whole tool (depending on the thickness of the material), moves pro-stop to the surface of the workpiece, according to the direction of the press. Its construction corresponds to the classic construction of stamps.

On the other hand, for the finishing part $(A)$ of the punch, separated from the coarse part by the constriction (4), an additional rotary movement is introduced. As it is equipped 
with cutting blades (1) placed on the circumference, the classic cutting process (drilling) takes place, and as a result smoothing the opening surface. In addition, the flash on the underside of the workpiece is cut off.

The finishing part starts with a cut, the angle of which depends on the material being processed and has a diameter larger by approx. $0.1 \div 0.2 \mathrm{~mm}$, consistent with the nominal dimensions of the hole being made.

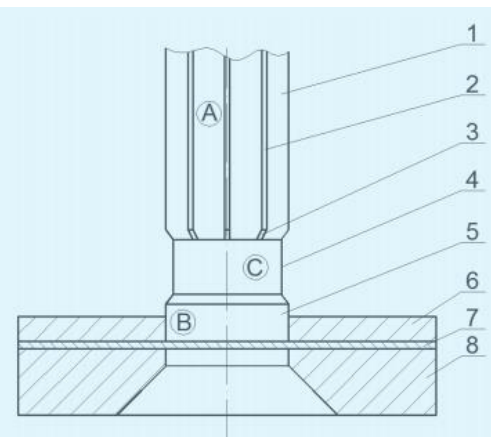

Fig. 4. Tool for punching and reaming holes in high accuracy classes: A - finishing part, B - roughing part, C - narrowing. 1 - cutting blades with straight contour, 2 - blades, 3 - pattern, 4 - roller-shaped narrowing, 5 - punching die, 6 - guide plate, 7 - punched material, 8 - matrix

\section{Conclusions}

Using the advanced CAD/CAE system AutoDesk Inventor 2015 [6], a design of a threading head and a special tool for punching and reaming holes in a multi-tension press were developed. The reconstructed head is universal and meets the requirements set for the devices in the threading and drilling processes.

The use of CAD software enables simple replacement of individual head modules: bolt-wheel screws and a set of gears forming a gearing. Based on 3D models, the constructor can check the kinematic correctness of the mechanism and perform strength calculations in the CAE module.

The presented tapping head on the press is a universal device. Basic device parameters presented in the article were calculated for the classical threading process using cutting taps up to a maximum diameter of $40 \mathrm{~mm}$. In the case of embossing the internal thread, there are much larger torsional moments than in the threading of a cutting screw, which makes this method require a much higher torque. This is related to the design changes of the ball screw and the gear ratio.

Due to the use of CAD/CAE tools based on the existing 3D model, the head was redesigned and its parameters for thread embossing adjusted. This speeds up the process of creating subsequent versions of the device for other types of tapping and reaming. At the same time, the other elements of the head do not change, but most of all the shape and size of the housing as well as the spacing and mounting method on the matrix board, which facilitates the re-multiplication of the multi-measure tool depending on the task being performed.

The developed punching and reaming tool has a simple design, is very accurate and convenient to use. It can be a monolithic or folding tool equipped with replaceable blade or blades made of super-hard materials. It allows you to drill round holes in a single press operation without the need for additional operations or technological operations.

The obtained hole is characterized by high dimensional accuracy and low roughness of side surfaces and is within the limits of accuracy classes IT5 $\div$ IT7. In addition, there is no flash. The tool also allows you to get the exact cutting line. As a result, the economic efficiency of production increases and its time is shortened. Instead of only a few technological treatments, only one is required.
In the case of making the tool as a folding, the machining technology and construction, which is the subject of the study, facilitates its further operation. Moreover, it enables the processing of round-shaped chimneys, which in the case of other constructions, even equipped with movable substamps, is practically impossible.

\section{REFERENCES}

1. Cichosz P. „Narzędzia skrawające”. Warszawa: Wydawnictwo WNT, 2006, 2013.

2. Dul-Korzyńska B. „Obróbka skrawaniem i narzędzia”. Rzeszów: Oficyna Wydawnictwa Politechniki Rzeszowskiej, 2005.

3. Górecki A. „Technologia ogólna, podstawy technologii mechanicznych". Warszawa: WSiP, 2009.

4. Gwiazdowski W. „Kinematyka obrabiarek”. Warszawa: Wydawnictwo WNT, 1965.

5. http://eurometal.com.pl/prasy-hydrauliczne-euromet-ph.html

(February, 2017)

6. http://www.autodesk.pl (February, 2017).

7. Juchnikowski W. Żółtowski J. „Podstawy konstrukcji maszyn”.

Warszawa: Oficyna Wydawnicza Politechniki Warszawskiej, 2004.

8. FANAR catalogue. „Narzędzia do gwintów”. 2014.

9. HENNLICH catalogue. „Sprężyny naciskowe”. 2014.

10. HIWIN GmbH catalogue. „Mechanizmy śrubowo-toczne i wyposażenie", 2012.

11. NSK catalogue. „Łożyska toczne. Katalog nr. E1102f”. 2009.

12. Koneczny D. „Konstrukcja głowicy do gwintowania w procesie wycinania elementów z blachy". Praca inżynierska pod kierunkiem A. Piotrowskiego. Politechnika Częstochowska, 2017.

13. Kurmaz L., Kurmaz O. „Projektowanie węzłów i części maszyn”. Kielce: Wydawnictwo Politechniki Świętokrzyskiej, 2003.

14. Kurmaz L. „Podstawy konstrukcji maszyn”. Warszawa: Wydawnictwo PWN, 1999.

15. Kuryjański R. „Metody nacinania gwintów”. Warszawa: IPBM Politechnika Warszawska, 1996

16. Mazanek E. „Przykłady obliczeń z podstaw konstrukcji maszyn”. Warszawa: Wydawnictwo WNT, 2005.

17. Norma PN-EN 22857:1999 - Gwintowniki z zarysem szlifowanym do gwintów metrycznych ISO zwykłych i drobnozwojnych z polami tolerancji od $4 \mathrm{H}$ do $8 \mathrm{H}$ i od $4 \mathrm{G}$ do $6 \mathrm{G}$ - Tolerancje części roboczej.

18. Norma PN-ISO 724:1995 - Gwinty metryczne ISO ogólnego przeznaczenia - Wymiary nominalne.

19. Norma PN-ISO 965-1 i 2:2001 - Gwinty metryczne ISO ogólnego przeznaczenia - Tolerancje - Część 1: Zasady i dane podstawowe. 20. Norma PN-ISO 965-3:2001 Norma PN-ISO 965-3:2001 - Gwinty metryczne ISO ogólnego przeznaczenia - Tolerancje - Część 3: Odchyłki gwintów maszynowych.

21. Olszak W. „Obróbka skrawaniem”. Warszawa: Wydawnictwo WNT, 2009.

22. Pater Z., Samołyk G. „Podstawy technologii obróbki plastycznej metall”. Lublin: Wydawnictwo Politechniki Lubelskiej, 2013.

23. Ponieważ G., Kuśmierz L. „Podstawy konstrukcji maszyn. Projektowanie mechanizmów śrubowych oraz przekładni zębatych". Lublin: Wydawnictwo Politechniki Lubelskiej, 2011.

24. Pronic. „Gwintowanie bezwiórowe na prasie”. 2010.

25. Sandvik Coromant Academy. „Podstawy obróbki skrawaniem”. Wydanie 2010.

Translation of scientific articles, their computer composition and publishing them on the website www.mechanik.media.pl by original articles in Polish is a task financed from the funds of the Ministry of Science and Higher Education designated for dissemination of science.

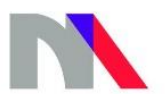

Ministry of Science and Higher Education

Republic of Poland 